\author{
Martyna Pańczak \\ ORCID: 0000-0001-6363-9774 \\ Uniwersytet Wrocławski
}

\title{
A imię jej czterdzieści i cztery. W stronę kanonu (bardziej) otwartego
}

DOI: $10.19195 / 0867-7441.24 .27$

Recenzja: ...czterdzieści i cztery. Figury literackie. Nowy kanon, red. Monika Rudaś-Grodzka, Barbara Smoleń, Katarzyna Nadana-Sokołowska, Agnieszka Mrozik, Katarzyna Czeczot, Anna Nasiłowska, Ewa Serafin-Prusator, Agnieszka Wróbel, IBL PAN, Warszawa 2016, ss. 698.

Słowa kluczowe: figura, kanon, fantazmat, romantyzm, krytyka feministyczna, kultura popularna

Keywords: figure, canon, phantasm, Romanticism, feminist criticism, popular culture

...czterdzieści i cztery. Figury literackie. Nowy kanon to kolejne z dużych wydawniczych przedsięwzięć grona badaczek związanych z Instytutem Badań Literackich Polskiej Akademii Nauk, w ostatnich latach odpowiedzialnych między innymi za publikację ważnego dla rozwoju rodzimej dziedziny gender studies podręcznika Encyklopedia gender. Pteć w kulturze $e^{1}$. Obecnie znaczna część zespołu redakcyjnego tomu realizuje także projekt „Archiwum Kobiet”, mający na celu odnajdywanie i archiwizowanie niepublikowanych dotąd rękopisów - dzieł literackich, listów, dzienników i pamiętników - autorstwa kobiet zamieszkujących ziemie polskie w kilku ostatnich stuleciach. Wszystkie inicjatywy charakteryzuje tendencja do syntetyzowania bądź porządkowania, wszystkie zdradzają przy tym wysokie ambicje kryjące się za tytułowymi określeniami „encyklopedia”, ,archiwum” czy „nowy kanon”. Również obszar zainteresowań badaczek, a także stawiane sobie przez nie zadania, pozostają te same. Skupiając się na zagadnieniach związanych z kategorią płci, zwłaszcza społeczno-kulturowej, oraz przyznając pierwszeństwo problematyce kobiecego pisania i doświadczenia, pomysłodawczynie projektów dążą do ożywienia naukowej refleksji dotyczącej kategorii „kobiecości”, a w konsekwencji do pogłębienia wiedzy o udziale i roli kobiet w polskiej tradycji kulturowej i literackiej.

Artykuły zamieszczone w pokaźnym, niemal siedmiuset stronicowym tomie poświęcone zostały czterdziestu czterem figurom związanym z kobiecością i sposobami jej funkcjonowania w polskiej wyobraźni kulturowej. Tytułowe „fi-

${ }^{1}$ Encyklopedia gender. Płeć w kulturze, red. M. Rudaś-Grodzka et al., Warszawa 2014. 
gury literackie" definiowane są przez redaktorki szeroko. Jak piszą we wstępie, przez pojęcie to należy rozumieć ,,postać historyczną lub fikcyjną, która w procesie zmian historycznych i społecznych nabrała znaczenia albo symbolicznego, albo alegorycznego, stając się podejmowanym i reinterpretowanym wciąż na nowo przez kolejne pokolenia wątkiem kulturowym znacząco wpływającym na konstrukcje tożsamościowe, uwikłane w kategorię płci kulturowej"2. Konstrukcjami tymi są na przykład naród, wspólnota etniczna, klasa czy mniejszość seksualna, z którymi identyfikują się osoby przynależące do danej zbiorowości. Przyjmując podobne założenia oraz korzystając z instrumentarium badawczego wypracowanego na gruncie dyskursu feministycznego i, szerzej, kulturowego, autorki i autorzy ${ }^{3}$ tekstów otwarcie deklarują chęć poszerzenia perspektywy przyjmowanej do analizy i interpretacji wyobrażeń, symboli czy fantazmatów kobiety i kobiecości charakterystycznych dla polskiej literatury i kultury. Ich celem jest wyznaczenie nowych możliwości ujmowania zjawisk, których znaczenia, jak uzmysławia lektura poszczególnych artykułów, zawsze zakorzenione są w określonej ideologii oraz determinowane przez wartości podzielane przez zbiorowość (czy raczej grupę dominującą w owej zbiorowości) w pewnym konkretnym miejscu i czasie.

Tę nadrzędną intencję dobrze oddaje pytanie postawione przez Ingę Iwasiów: „jak czytać kanon literacki, będąc czytelniczką?"4 . Domyślnie zawiera się w nim bowiem rozpoznanie pewnych stałych kodów znaczeniowych, do których odwołujemy się, obcując z tekstami kultury. Kodów, które niczym Barthes’owskie déjà-lu składają się z tego, co już przez nas przeczytane lub poznane ${ }^{5}$, ale też które kształtowane są przez lektury innych, wcześniejszych, czytelników. Dotyczy to zwłaszcza figur kanonicznych. Ich wypracowane i wrośnięte w tradycję badawczą sposoby czytania tworzą swoisty rezerwuar możliwych sensów, który, jak pisze Iwasiów, ma ,zagarniającą moc, po pewnym czasie zaczyna szczelnie zasłaniać tekst, zastępuje osobisty kontakt z utworem"6. A przecież stawka lektury osobistej, naznaczonej prywatnym, uwarunkowanym między innymi płciowo,

${ }^{2}$ M. Rudaś-Grodzka, B. Smoleń, Wstęp, [w:] ...czterdzieści i cztery. Figury literackie. Nowy kanon, red. M. Rudaś-Grodzka et al., Warszawa 2016, s. 11-12.

${ }^{3} \mathrm{~W}$ artykule posługuję się rozróżnieniem form rzeczowników na żeńskie i męskie, idąc za przykładem samych redaktorek recenzowanego tomu (zob. np. ibidem, s. 13, 14). Biorąc pod uwagę zdecydowanie przeważającą liczbę kobiet w zespole, wydaje mi się to szczególnie uzasadnione. Wybór ten wiąże się także $\mathrm{z}$ diagnozą niedoreprezentowania płci żeńskiej, nie tylko w licznych sferach życia społecznego i publicznego, w tym naukowego, lecz także w samym języku (zob. np. M. Karwatowska, J. Szpyra-Kozłowska, Językowa niewidzialność kobiet we współczesnej polszczyźnie, „Stylistyka” 2004, nr 13, s. 35-53).

${ }^{4}$ I. Iwasiów, Lalka, [w:] ...czterdzieści i cztery, s. 314.

${ }^{5}$ R. Barthes, S/Z, przeł. M.P. Markowski, M. Gołębiewska, wstęp M.P. Markowski, Warszawa 1999.

${ }^{6}$ I. Iwasiów, op. cit., s. 313. 
doświadczeniem ${ }^{7}$, jest wysoka — zależy od niej uznanie narodowej tradycji za własną. Jak zatem czytać kanon, będąc czytelniczką? Odpowiedź ma stanowić postulat wyjścia poza odbiorcze, w tym badawcze, przesądy i stereotypy. Sądzę, że zostaje on spełniony wzorcowo. To właśnie odczytana na nowo figura kobiety, której wymowa zawsze uzależniona była od społecznego horyzontu oczekiwań, a także wpisana w jej definicję otwartość, niekonkluzywność charakterystyczna dla wszelkich figur mniejszościowych, mają szansę podać w wątpliwość niektóre z poznawczych i interpretacyjnych pewników, tym samym powodując wyrwę w zastanym systemie znaczeń.

Nie tylko kanon polskiej kultury jest jednakże przedmiotem rozważań w artykułach składających się na tom ...czterdzieści $i$ cztery. Obok postaci na trwałe już zdaje się osadzonych w zbiorowej pamięci kulturowej, jak choćby bohaterki szkolnych lektur (Balladyna, Róża Żabczyńska, Siłaczka, Zosia z Pana Tadeusza) czy znane z kart historii bohaterki narodowe (Barbara Radziwiłłówna, Emilia Plater), omówione zostały postacie słabiej dziś pamiętane, a niekiedy i zepchnięte na margines najnowszej refleksji krytycznej czy naukowej. Nie chodzi przy tym wyłącznie o upomnienie się o miejsce w kanonie dla owych figur, ale również, a może przede wszystkim, o uwydatnienie kulturowej, etnicznej, a nawet seksualnej różnorodności w obrębie kształtowanych przez literaturę i kulturę modeli podmiotowości - o przypomnienie, że w polskiej tradycji mieści się także to, co $\mathrm{z}$ różnych powodów nienormatywne. Figury kobiecości to bowiem także Cyganka Aza z Chaty za wsia Ignacego Kraszewskiego, bohaterka wielowymiarowa, ikona władzy i wolności, której kreacja przełamuje konwencje pisania zarówno o kobietach „orientalnych”, jak i o romskiej społeczności; to wymykająca się binarnym opozycjom płci, genderu, seksualności postać Marii Komornickiej/Piotra Odmieńca Własta; to wiedźma Horpyna z Ogniem i mieczem Henryka Sienkiewicza, której figura czytana w perspektywie kulturowej odsłania cierpienie rzeczywistych kobiet oskarżanych o czary — kobiet wykluczonych, stygmatyzowanych, torturowanych z powodu swojej odmienności.

Uwidocznia się tu jeszcze jeden interesujący mnie aspekt pracy. Otóż próba zebrania istotnych dla polskiej wspólnoty wyobrażonej ${ }^{8}$ figur, zbiorowych fantazmatów kobiecości, wiąże się z koniecznością sięgnięcia do wielu różnych poziomów czy obiegów kultury - niejako ponad podziałami na kulturę elitarną i kulturę popularną, na to, co uznawane za „wysokie” lub „niskie”. To bowiem, co za pomocą symboli i kodów kształtuje wspólnotowy dyskurs tożsamościowy, to nie tylko kanon wysokoartystycznej literatury. Przeciwnie, na kulturowe imaginarium

${ }^{7}$ Rozmaite ujęcia oraz konsekwencje teoretyczne tego problemu przedstawia Jonathan Culler, Reading as a Woman, [w:] On Deconstruction. Theory and Criticism after Structuralism, New York 1982, s. 43-64.

${ }^{8} \mathrm{~W}$ tym znaczeniu, w jakim pisał o tym pojęciu Benedict Anderson, Wspólnoty wyobrażone. Rozważania o źródłach i rozprzestrzenianiu się nacjonalizmu, przeł. S. Amsterdamski, Kraków-Warszawa 1997, s. 19-21. 
składają się w równym stopniu literatura popularna, plakaty, zdjęcia, piosenki, seriale odwołujące się do zbiorowej wrażliwości i wpływających na ową wrażliwość doświadczeń. Autorki i autorzy omówień zebranych w tomie ...czterdzieści $i$ cztery dobrze zdają sobie z tego sprawę. Świadczą o tym nie tylko artykuły-hasła poświęcone takim postaciom, jak tytułowa bohaterka piosenki Kazika i El Dupy Natalia w Brooklynie, Marusia z Czterech pancernych i psa czy tytułowa „Panna z mokrą głową” z powieści Kornela Makuszyńskiego. Bardzo ważna jest również gotowość badaczek i badaczy do czynienia rozmaitych odniesień, kreślenia nieprzewidzianych linii skojarzeń, które pozwalają połączyć niektóre figury z ich realizacjami współczesnymi, często właśnie popkulturowymi. W tym duchu uwspółcześnione wcielenie Judyty Monika Rudaś-Grodzka dostrzega w filmach wykorzystujących motyw kobiety-mścicielki, a jedno z odczytań legendy o Wandzie jako przywódczyni smoków sytuuje obok historii znanych z powieści i seriali fantasy ${ }^{9}$. O przepisywaniu zaś tradycji romantycznej przez literaturę popularną wspomina Michał Kuziak, przyglądając się alternatywnej wersji historii o Balladynie w powieści Sławomira Mrugowskiego Strzygonia. Dziedzictwo krwi ${ }^{10}$.

Analogie te dobrze pokazują żywotność figur w zbiorowej międzypokoleniowej świadomości. Podobne podejście ma zresztą swoją tradycję w twórczości naukowej Marii Janion, której dedykowana jest praca. Wybitna historyczka literatury, znawczyni romantyzmu, wnikliwa badaczka fantazmatów organizujących polską wyobraźnię, konsekwentnie łączy wyrafinowane rozważania filologiczne i filozoficzne z namysłem nad rozmaitymi zjawiskami kultury popularnej. W swych tekstach wielokrotnie uzmysławiała, że zrozumienie mitów, symboli, figur stanowiących ważne punkty odniesienia narodowej tożsamości, nigdy nie będzie całkowite bez wniknięcia w znaki i archetypy tkwiące w odwiecznych opowieściach, przekazywanych najpierw przez kulturę ludową, w tym tradycję ustną, następnie przez powielającą je literaturę gatunkową, aż po rozbudzającą emocje i tęsknoty masowego widza współczesną telenowelę. Innymi słowy, przez narracje bliskie potocznej i powszechnej świadomości, współtworzące dziś najczęściej właśnie literaturę i kulturę popularną.

W pracy byłych uczennic profesor Marii Janion (bo to głównie one brały udział w tworzeniu tomu) wyraźnie znać wpływ autorki Projektu krytyki fantazmatycznej. Już sam tytuł wydawnictwa, odwołujący się do jednej z najważniejszych figur romantycznego imaginarium - narodowego wieszcza, męża czterdzieści i cztery - choć potraktowany dość przewrotnie, bo w sposób sugerujący wewnętrzną niespójność, rozproszenie postaci wskrzesiciela narodu, zdradza przywiązanie do „wielkiej” symboliki narodowej, od której zdaniem Janion nie sposób się uwolnić. Nie oznacza to jednak wcale, że owa symbolika koniecznie musi być odczytywana w paradygmacie tyrtejsko-martyrologicznym. Badacz-

${ }^{9}$ Zob. M. Rudaś-Grodzka, Judyta, [w:] ...czterdzieści i cztery, s. 276; eadem, Wanda, [w:] ... czterdzieści i cztery, s. 635-636.

${ }^{10}$ M. Kuziak, Balladyna, [w:] ...czterdzieści i cztery, s. 71-72. 
ka dostrzegała możliwość zmiany sposobu istnienia romantyzmu w kulturowej pamięci, a warunkiem miało być odkrycie go na nowo ${ }^{11}$. Ideę tę najlepiej być może wyrażają słowa Tadeusza Konwickiego, przywoływane przez Janion: „Zamiast uciekać przed polskością, warto spróbować pójść w nią do końca"12. Zdaje się, że tom ...czterdzieści i cztery jest właśnie taką próbą. Artykuły wykorzystują nowoczesne perspektywy interpretacyjne, między innymi genderową, postkolonialną, psychoanalityczną, zadają nawet pytania sytuujące się na pograniczu refleksji charakterystycznej dla posthumanistyki czy wpisującego się w posthumanistyczne tendencje myślowe nurtu animal studies (odsyłam do tekstu o Małpce Fiki-Miki Anny Marii Czernow), by w nowym świetle ukazać motywy i figury obecne w polskiej kulturze od stuleci. To, co „polskie” — nasze, swojskie, ojczyźniane - zyskuje dzięki temu cenny walor aktualności. Przestaje być gotowym, skostniałym modelem polskości utrwalonym na kartach podręczników do historii, w zamian okazując się wciąż żywym, inspirującym składnikiem współczesnych narracji tożsamościowych. Warto przy tym dodać, że bez odniesień do kultury popularnej oraz innych zjawisk wykraczających poza wysokoliterackie wzorce zamierzenie to straciłoby na autentyczności.

Choć nie wszystkie teksty prezentują przełomowe, zupełnie nowatorskie analizy (dotyczy to zwłaszcza omówień postaci o silnej pozycji w polskiej humanistyce, które zdążyły już wcześniej doczekać się reinterpretacji w kluczu feministycznym czy genderowym, jak choćby Róża Żabczyńska, Iwona z Iwony, księżniczki Burgunda Witolda Gombrowicza albo Madzia Brzeska z Emancypantek Bolesława Prusa), niewątpliwie zyskują one w zestawieniu z innymi - w całości, jaką stanowi przyjmujący formę leksykonu tom ...czterdzieści i cztery. Jego hasłowy, alfabetyczny układ wiąże się co prawda z fragmentarycznością, a więc i nieuniknioną wyrywkowością oraz niekompletnością wywodu, z drugiej jednak strony otwiera możliwość snucia wielowątkowej opowieści o figurach kobiecości, a także innych figurach, często drugoplanowych, jeszcze niedostatecznie rozpoznanych. Opowieść ta jest przeglądem motywów, wątków, symboli, a przy tym tworzy swoisty katalog rzeczywistych kobiet — pisarek, artystek, działaczek które odegrały znaczącą rolę w kulturze. Autorki i autorzy wykazują się wielką erudycją, zarysowując rozległe konteksty kulturowe, społeczne, historyczne i ekonomiczne, na których tle ukazywane są poszczególne figury. Dzięki temu polska tradycja kulturowa jawi się w swej wieloznaczności i heterogeniczności, a kwestia złożonej zbiorowej tożsamości zostaje postawiona jako problem wymagający rozwiązania.

Sygnalizowałam już, że katalogowy, syntetyzujący, a nawet podręcznikowy charakter tomu sytuuje go obok wydanej kilka lat wcześniej Encyklopedii gender. Obie publikacje uznać można więc za oznaki postępującej autonomizacji i insty-

11 Zob. M. Janion, Wolny rynek marzeń, [w:] Projekt krytyki fantazmatycznej. Szkice o egzystencjach ludzi i duchów, Warszawa 1991, s. 6.

12 Ibidem, s. 5. 
tucjonalizacji dyscypliny gender studies na gruncie polskiej humanistyki, o czym pisał niedawno Przemysław Górecki ${ }^{13}$. Metodologiczne źródła pracy dostrzec można natomiast w pozycjach prekursorskich dla feministycznie i genderowo zorientowanych badań nad polską literaturą, takich jak Grażyny Borkowskiej $\mathrm{Cu}$ dzoziemki czy Krystyny Kłosińskiej Ciało, pożądanie, ubranie ${ }^{14}$. Właściwie cała seria wydawnicza „Lupa Obscura”, w której ukazuje się ...czterdzieśsi i cztery, zawdzięcza wiele przetartym tam drogom lektury wykorzystującej pojęcia i kategorie wypracowane na przykład na gruncie francuskiej krytyki feministycznej czy psychoanalizy Jacques'a Lacana i Julii Kristevej. Postulat przewartościowania dotychczasowych znaczeń figur i fantazmatów skłania również do szukania analogii z książką Kazimiery Szczuki Kopciuszek, Frankenstein i inne ${ }^{15}$, która miała być przyczynkiem do alternatywnej historii literatury. W swej całościowej wymowie praca ...czterdzieści i cztery, złożona z artykułów pisanych różnym stylem, często nastawionych raczej na podsumowanie, udokumentowanie momentów zwrotnych w biografiach symbolicznych omawianych postaci, ma jednak mniej radykalnie rewizjonistyczny charakter ${ }^{16}$.

Pewną słabość tomu upatrywać można w fakcie, iż autorki i autorzy tekstów wywodzą się w zdecydowanej większości z jednego środowiska literaturoznawczego. Prowokuje to bowiem pytanie o status konstruowanego - zgodnie z tytułowym postulatem - nowego kanonu. Czy nie staje się on wyłącznie kolejną petryfikującą formą narzucaną przez grupę znawczyń; kolejnym ograniczonym zbiorem figur oraz sposobów ich odczytań, które od dziś kształtować powinny polską pamięć zbiorową? W końcu tworzenie standardów lekturowych, wskazywanie postaci lub problemów mających uchodzić za ważniejsze od innych zawsze uruchamia jakiś selektywny mechanizm. Wiąże się to ze swoistością samej kanoniczności oraz związanych z nią procesów. Przyjąwszy konkretne, nierzadko arbitralne, kryteria, jedne zjawiska się uprzywilejowuje, drugie zaś pomija, a zatem wyklucza. Również próba ustanowienia nowego kanonu przez zespół związany z IBL-owskim ośrodkiem podjęta zostaje z wyraźnie określonej perspektywy. Jej fundament to, rzecz jasna, założenia teorii feministycznej.

Niemniej, trudno przeoczyć z gruntu otwartą, podatną na polemikę i kwestionowanie, formułę pracy ...czterdzieści i cztery. Autorki i autorzy tekstów rzadko dają ostateczne odpowiedzi na stawiane przez siebie pytania, nie starają się też

${ }^{13}$ P. Górecki, Z marginesów do centrum: „Encyklopedia gender” $i$ inne nowe omówienia a przemieszczanie dyscypliny gender studies, „Teksty Drugie” 2017, nr 1, s. 128-138.

14 G. Borkowska, Cudzoziemki. Studia o polskiej prozie kobiecej, Warszawa 1996; K. Kłosińska, Ciało, pożadanie, ubranie. O wczesnych powieściach Gabrieli Zapolskiej, Kraków 1999.

15 K. Szczuka, Kopciuszek, Frankenstein i inne. Feminizm wobec mitu, Kraków 2001.

16 Ów rewizjonizm rozumiem tu w duchu klasycznej już wykładni Sandry Gilbert, która pisała o dążeniu krytyki feministycznej do rozpoznania i obnażenia relacji pomiędzy tekstualnością a seksualnością, tożsamością psychoseksualną a wpływem kulturowych autorytetów (eadem, What do Feminist Critics Want? A postcard from the Volcano, [w:] The New Feminist Criticism: Essays on Women Literature, and Theory, red. E. Showalter, New York 1985, s. 36). 
narzucić całościowych wykładni analizowanych utworów czy wątków. Inkluzywność proponowanego kanonu poświadcza również praktyka odnotowywania licznych asocjacji i potencjalnych związków, które mogą zachęcać do dalszej pracy, do wydobywania kolejnych sensów i śledzenia nieustających przekształceń znaczeń nabudowanych wokół figur kulturowej wyobraźni. Warto nadmienić przy tym, że gros omawianych w tomie postaci od dawna już współtworzy narodową tradycję, o czym osadzone w szerokim kontekście kulturowym i historycznoliterackim artykuły nie pozwalają zapomnieć. Celem pracy nie jest więc wcale, jak mógłby sugerować dość prowokacyjny tytuł, radykalny gest zerwania z tradycją i zastąpienie obowiązującego kanonu nowym, w równym stopniu roszczącym sobie prawo do uniwersalności. Ważniejsze wydaje się rozszczelnienie granic kanonu już istniejącego, co umożliwić ma włączenie weń i poddanie dyskusji nowych problemów, choćby wzmiankowanego przeze mnie problemu wielości możliwych pozycji, z jakich określać się można względem polskości czy kobiecości. Ich sformułowanie stanowi warunek podjęcia odpowiedzialnego, konstruktywnego dialogu między członkami dzisiejszej polskiej wspólnoty.

Taki sposób myślenia o kanonie - jako zbiorze wciąż kształtowanym, elastycznym, „słabym” — wikła się rzecz jasna w rozmaite paradoksy, z których największy polega na sprzeczności między źródłosłowem pojęcia, odsyłającym do „wzorca”, „modelu”, „miary”, a nawet „normy”"17, a nową propozycją jego rozumienia, która podważałaby jego stałość, niezmienność i, nade wszystko, normatywność. A jednak, zdając sobie sprawę, że za uznaną literaturą oraz za przypisywanymi jej znaczeniami i wartościami zawsze stoi jakaś instytucja, jestem skłonna przystać na to nowe, niekanoniczne, ujęcie. Może to właśnie paradoks jest w stanie najlepiej oddać charakter każdego kanonu, będącego zbiorem domagającym się prawomocności, a często i wyłączności, za którego legitymizację zawsze wszakże odpowiedzialny jest określony, ale niekoniecznie uniwersalny, autorytet. Niezależnie bowiem od tego, czy pod pojęciem kanonu rozumieć będziemy zestaw tekstów funkcjonujących w powszechnym obiegu czytelniczym danej społeczności, ogół związanych z nimi konwencjonalnych sensów, czy też, bardziej usystematyzowany, spis lektur obowiązujących na kolejnych etapach szkolnej edukacji, jego powstawanie i utrwalanie pozostaje w ścisłym związku $\mathrm{z}$ władzą. Bywa ona upodmiotowiona lub ześrodkowana w konkretnej instytucji, bywa również odcieleśniona, rozproszona w rozmaitych dyskursach. Istotne, że umacniane przez nią hierarchie - wartości estetycznych, poznawczych czy ideowych - są historycznie względne; wyznaczają normy do czasu, w którym nie wyłoni się siła gotowa, by zastany porządek zrewaluować.

W tym kontekście niezmiernie ciekawie brzmi uwaga Jerzego Święcha, który pisząc o kanonie nowoczesnym, sygnalizował tkwiącą w nim ideę samozniesienia.

${ }^{17}$ Zob. np. rozważania Doroty Kozickiej, Wołanie o kanon? Znamienne wątki dyskusji metakrytycznych na przełomie wieków, [w:] Kanon i obrzeża, red. I. Iwasiów, T. Czerska, Kraków 2005, s. 54. 
Powołując się po części na tezy Harolda Blooma, stwierdzał: „Jak długo kanon stanowi bodziec do nowych interpretacji, a jako norma jak silnie wzmacnia potrzebę ograniczenia jej bezwzględnych roszczeń lub wręcz jej obalenia, tak długo dowodzi potrzeby swojego istnienia"18. Czy mając świadomość niestałości standardów, nie należałoby uznać tych słów za jedyną możliwą dziś definicję kanonu? Jako „norma świadoma swoich hegemonistycznych uzurpacji i zarazem gotowa, by je w każdej chwili zakwestionować" ${ }^{19}$, byłby to kanon, którego ujawniona względność, perspektywiczność — tu wyciągam już własne wnioski — dawałaby więcej swobody w wyborze form współuczestniczenia w kulturze. Otwarcie zbioru figur literackich, a zwłaszcza odebranie dotychczasowym ich odczytaniom praw do uniwersalności i ostateczności pociąga zatem co prawda istotową zmianę w tworze, jakim jest kanon, ale jednocześnie pozwala zachować samą ideę kanoniczności, a przede wszystkim umożliwia podtrzymanie jej najważniejszych w moim przekonaniu funkcji — funkcji kulturotwórczej z jednej strony, z drugiej zaś, zależnej od niej, funkcji spajania wspólnoty, a zatem wyznaczania obszaru wzajemnego (po)rozumienia, a kiedy to konieczne, również mediowania pomiędzy odległymi od siebie, często trudnymi do pogodzenia, dążeniami rozmaitych grup i społeczności składających się na współczesne polskie społeczeństwo.

\section{Bibliografia}

\section{Opracowania}

Anderson B., Wspólnoty wyobrażone. Rozważania o źródłach i rozprzestrzenianiu się nacjonalizmu, przeł. S. Amsterdamski, Znak, Kraków-Warszawa 1997.

Barthes R., S/Z, przeł. M.P. Markowski, M. Gołębiewska, wstęp M.P. Markowski, Wydawnictwo KR, Warszawa 1999.

Borkowska G., Cudzoziemki. Studia o polskiej prozie kobiecej, Wydawnictwo Instytut Badań Literackich PAN, Warszawa 1996.

Culler J., Reading as a Woman, [w:] On Deconstruction. Theory and Criticism after Structuralism, Cornell University Press, New York 1982.

Encyklopedia gender. Pleć w kulturze, red. M. Rudaś-Grodzka et al., Wydawnictwo Czarna Owca, Warszawa 2014.

Gilbert S., What do Feminist Critics Want? A postcard from the Volcano, [w:] The New Feminist Criticism: Essays on Women Literature, and Theory, red. E. Showalter, Pantheon Books, New York 1985.

Górecki P., Z marginesów do centrum: Encyklopedia gender i inne nowe omówienia a przemieszczanie dyscypliny gender studies, „Teksty Drugie” 2017, nr 1.

Iwasiów I., Lalka, [w:] ...czterdzieści i cztery. Figury literackie. Nowy kanon, red. M. Rudaś-Grodzka et al., Wydawnictwo Instytut Badań Literackich PAN, Warszawa 2016.

Janion M., Gorączka romantyczna, Państwowy Instytut Wydawniczy, Warszawa 1975.

18 J. Święch, Burze wokół kanonu/kanonów, [w:] Kanon i obrzeża, s. 20.

${ }^{19}$ Ibidem. 
Janion M., Wolny rynek marzeń, [w:] Projekt krytyki fantazmatycznej. Szkice o egzystencjach ludzi i duchów, Wydawnictwo PEN, Warszawa 1991.

Kłosińska K., Ciało, pożądanie, ubranie. O wczesnych powieściach Gabrieli Zapolskiej, Wydawnictwo „eFKa”, Kraków 1999.

Karwatowska M., Szpyra-Kozłowska J., Językowa niewidzialność kobiet we współczesnej polszczyźnie, „Stylistyka” 2004, nr 13.

Kozicka D., Wołanie o kanon? Znamienne watki dyskusji metakrytycznych na przełomie wieków, [w:] Kanon i obrzeża, red. I. Iwasiów, T. Czerska, Universitas, Kraków 2005.

Kuziak Michał, Balladyna, [w:] ...czterdzieści i cztery. Figury literackie. Nowy kanon, red. M. Rudaś-Grodzka et al., Wydawnictwo Instytut Badań Literackich PAN, Warszawa 2016.

Rudaś-Grodzka M., Judyta, [w:] ...czterdzieści i cztery. Figury literackie. Nowy kanon, red. M. Rudaś-Grodzka et al., Wydawnictwo Instytut Badań Literackich PAN, Warszawa 2016.

Rudaś-Grodzka M., Wanda, [w:] ...czterdzieści i cztery. Figury literackie. Nowy kanon, red. M. Rudaś-Grodzka et al., Wydawnictwo Instytut Badań Literackich PAN, Warszawa 2016.

Rudaś-Grodzka M., Smoleń B., Wstęp, [w:] ...czterdzieści i cztery. Figury literackie. Nowy kanon, red. M. Rudaś-Grodzka et al., Wydawnictwo Instytut Badań Literackich PAN, Warszawa 2016.

Szczuka K., Aza, [w:] ...czterdzieści i cztery. Figury literackie. Nowy kanon, red. M. Rudaś-Grodzka et al., Wydawnictwo Instytut Badań Literackich PAN, Warszawa 2016.

Szczuka K., Kopciuszek, Frankenstein i inne. Feminizm wobec mitu, Wydawnictwo „eFKa”, Kraków 2001.

Święch J., Burze wokót kanonu/kanonów, [w:] Kanon i obrzeża, red. I. Iwasiów, T. Czerska, Universitas, Kraków 2005.

\section{Malwina Dziekan}

ORCID: 0000-0002-2965-7511

Uniwersytet Wrocławski

\section{Detektywi wiecznie żywi}

DOI: $10.19195 / 0867-7441.24 .28$

Recenzja: Tadeusz Cegielski, Detektyw w krainie cudów. Powieść kryminalna i narodziny nowoczesności 1841-1941, Wydawnictwo W.A.B. — Grupa Wydawnicza Foksal, Warszawa 2015, ss. 374.

Słowa kluczowe: literatura kryminalna, początki kryminału, historia literatury, literatura angielska, literatura amerykańska

Keywords: crime novel, the beginning of the crime novel, history of literature, English literature, American literature

Literatura popularna, w dawniejszych czasach raczej niedoceniana, we współczesnym świecie zaczęła święcić tryumfy. Choć wciąż rozpatrywana jest w opozycji do literatury wysokiej, według Anny Martuszewskiej jej lektura może stać się 